\title{
FEMP Fiscal Year 1999 ESPC Business Strategy Development Summary Report
}

Kate McMordie-Stoughton

Dave Hunt

March 2000

Prepared for the

U.S. Department of Energy

Office of Energy Efficiency and Renewable Energy

Federal Energy Management Program

Under Contract DE-AC06-76RLO 1830 


\section{DISCLAIMER}

This report was prepared as an account of work sponsored by an agency of the United States Government. Neither the United States Government nor any agency thereof, nor any of their employees, make any warranty, express or implied, or assumes any legal liability or responsibility for the accuracy, completeness, or usefulness of any information, apparatus, product, or process disclosed, or represents that its use would not infringe privately owned rights. Reference herein to any specific commercial product, process, or service by trade name, trademark, manufacturer, or otherwise does not necessarily constitute or imply its endorsement, recommendation, or favoring by the United States Government or any agency thereof. The views and opinions of authors expressed herein do not necessarily state or reflect those of the United States Government or any agency thereof. 


\section{DISCLAIMER}

Portions of this document may be illegible in electronic image products. Images are produced from the best available original document. 


\section{PREFACE}

The mission of the U.S. Department of Energy's Federal Energy Management Program (FEMP) is to reduce the cost of Government by advancing energy efficiency, water conservation, and the use of solar and other renewable technologies. This is accomplished by creating partnerships, leveraging resources, transferring technology, and providing training and technical guidance and assistance to agencies. Each of these activities is directly related to achieving requirements set forth in the Energy Policy Act of 1992 and the goals that have been established in Executive Order 13123 (June 1999), but also those that are inherent in sound management of Federal financial and personnel resources.

The Pacific Northwest National Laboratory (PNNL) supports the FEMP mission in all activity areas. This responsibility includes working with various Federal energy managers to identify, monitor, and evaluate the performance of new energy efficiency technologies suitable for installation at Federal sites.

This report provides the results of a Energy Saving Performance Contracting (ESPC) Business Strategy Development project that PNNL conducted for FEMP. The project provides information regarding the development of Federal market scenarios for FEMP Super-ESPC delivery orders. Two market scenarios were developed. The initial scenario resulted in an estimated delivery order target that was much lower than initially estimated in the spring of 1998 . The second scenario yielded a lower estimated number of delivery orders. The main difference between these two scenarios was an estimated increase in utility financed projects in the Federal sector. 


\section{SUMMARY}

This report summarizes the objectives, activities, products, and recommendatins of the ESPC Business Strategy Development project. Work on this project began in July 1998 and was completed in December 1998, with the primary deliverable being a series of presentations at the FEMP Fall Meeting on October 27, 1998. Work completed under this task was performed primarily at the Pacific Northwest National Laboratory (PNNL) (Dave Hunt, Dave Eike, Kate McMordie-Stoughton, and Andrew Nicholls), with one project task completed by David Howard of the National Renewable Energy Laboratory. The DOE FEMP project manager was Tatiana Muessel.

The objective of this project was to assist DOE FEMP in defining the potential Federal sector market for FEMP-offered alternative financing services with a focus on SuperEnergy Savings Performance Contracts (Super-ESPCs). The starting point for this project was the goal established at the 1998 FEMP Spring Meeting to complete 3,370 delivery orders, resulting in a total capital investment in energy efficinency improvements of approximately $\$ 5.06$ billion by 2005 . The project itself consisted of seven distinct tasks, which when taken together, allowed for development of Federal market scenarios for FEMP Super-ESPC delivery orders. The first market scenario resulted in an estimated delivery order target of 678 with a corresponding capital investment of $\$ 1.03$ billion based on the assumpton of $\$ 1.5$ million in capital investment per delivery order. The second market scenario, which was developed as part of a working lunch at the October 27 meeting, yielded a delivery order target of 478 with a resulting capital investment of $\$ 678$ million, while again assuming $\$ 1.5$ million in capital investment per delivery order. The main difference between these two scenarios was the estimated increase in utility financed projects under the second scenario. However, in both cases the delivery order target was revised significantly downward from the original goal.

In addition to these findings, several recommendations for further analysis and research were made:

- Reevaluate the reimbursable services cash flow models based on modified delivery order goals developed by this project.

- Initiate and maintain real-time data collection of Super-ESPC project data.

- Develop an on-line tracking system that summarizes project data for both ongoing and completed projects on a real-time basis, and provides summary reports.

- Continue survey activities in fiscal year 1999 focusing on why agencies select a given alternative financing method and why agencies select certain FEMP Services packages. 
- Provide assistance to the DOE Regional Support Offices in characterizing and prioritizing outreach and client sites by developing a making available detailed, region-specific, facility data.

- $\quad$ Review and revise Super-ESPC delivery order goals at the 1999 FEMP Fall Meeting based on actual project data from fiscal year 1999. 


\section{CONTENTS}

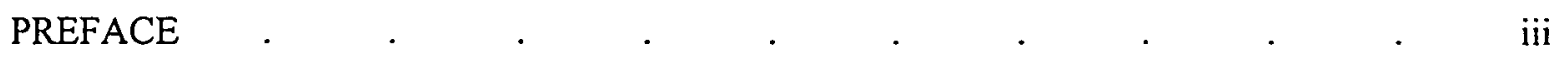

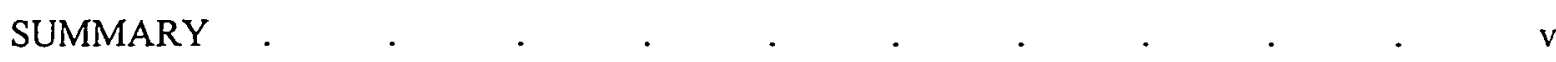

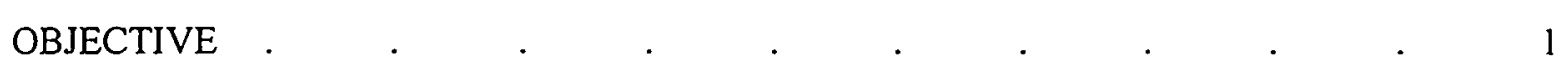

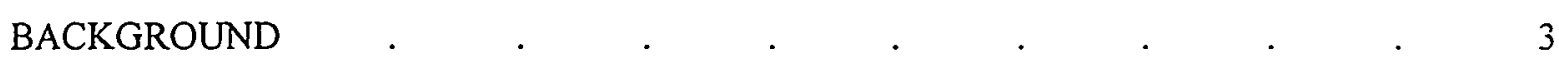

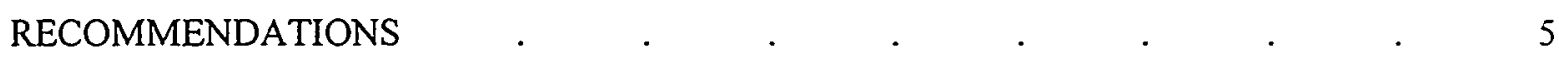

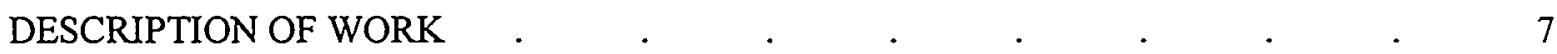

Task 1 - Describe the Universe of Federal Facilities by Kate
McMordie-Stoughton (PNNL) . . . . . . . .

Task 2 -- Alternative Financing Offerings in the Federal Sector

Task 5 -- Customer Surveys by Dave Hunt (PNNL) $\quad \ldots \quad \ldots \quad$. $\quad . \quad 9$

Tasks 3, 4, and 6 -- Determining Delivery Order Investment Potential and Defining FEMP "Niche" Market by Andrew Nicholls (PNNL) and

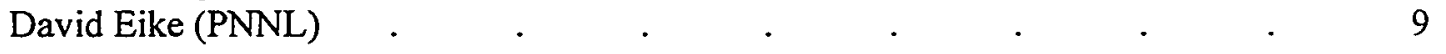

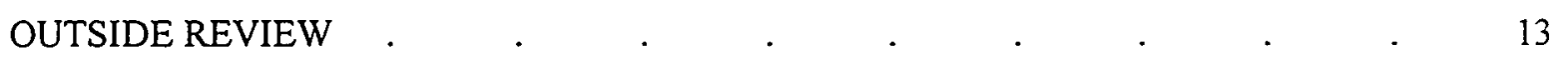

FSN Coordinating Council (October 29, 1998) $\quad$. $\quad . \quad$. $\quad . \quad$. 13

Arthur D. Little Report: A Review of Supporting Analysis for FEMP's

Super-ESPC Program . $\quad . \quad \ldots \quad . \quad$. $\quad . \quad$. $\quad . \quad 13$

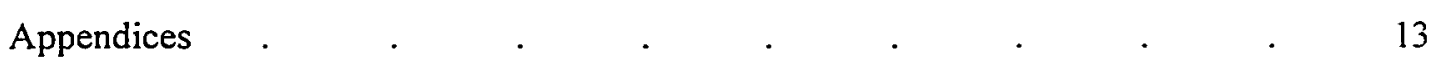

APPENDIX A - OCTOBER 27, 1998 POWER POINT PRESENTATION $\quad$ - _ $\quad$ A.1

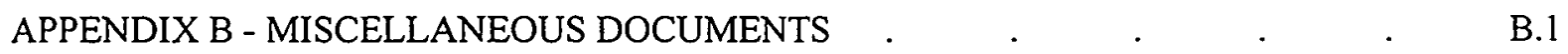




\section{TABLES}

1 Individual Agency Preferences for Alternative Financing $\quad . \quad$. $\quad \begin{array}{llll} & & 8\end{array}$

2 Market Share for Alternative Financing Options - Workshop Scenario . . 11

3 Market Share for Alternative Financing Options -- Utility Emphasis _ . . . 11 


\section{OBJECTIVE}

The objective of the ESPC Business Strategy Development Project is to develop a detailed understanding of the Federal market for Super-ESPC and Technology ESPC delivery orders (see Appendix B for complete statement of work). This understanding will assist FEMP in defining the market, assessing its role in that market, segmenting the market, and differentiating its approach to those segments. The analysis should allow more efficient assessment of resources required to service the FEMP "niche," and improve the efficiency and allocation of those resources, thus providing insight into how the FEMP Services (formerly referred to as the FEMP Services Network or FSN) can be an effective agent for ESPC delivery orders. 


\section{BACKGROUND}

At the 1998 FEMP Spring Meeting, a goal was established to complete 3,370 Super-ESPC delivery orders by 2005 . Some in attendance felt that the bases of this goal were neither clearly stated nor evaluated, specifically 1) a total level of investment in the Federal facility sector of around $\$ 5$ billion would be achieved primarily through FEMP Super-ESPCs, and 2) the average investment value of the delivery orders would be around $\$ 1.5$ million. There was general consensus among workshop participants that FEMP should perform a market analysis, through which these and other assumptions about the size and nature of the Super-ESPC market could be examined. The statement of work (Appendix B) was then developed, and the project was assigned to Tatiana Strainic Muessel (DOE FEMP) and Dave Hunt (PNNL) to manage and complete. The key focus of this project was to develop an understanding of the potential SuperESPC market - who, where, and how much. 


\section{RECOMMENDATIONS}

This market analysis provided FEMP with important insights into the size, composition and diversity of the market for Super-ESPC delivery orders. These insights have allowed FEMP to revise its Super-ESPC delivery order projections to better reflect realistic expectations regarding potential market size, and facility energy use characteristics, among other important factors. These projections represent a valuable resource for planning and managing FEMP activities.

This project was completed in 4 months, a very short time frame for a market analysis. Despite the initial success of this "fast tracked" project, additional research and analysis activities are required to ensure the long-term value of this effort to FEMP. These activities are necessary to overcome two distinct challenges. First, a significant level of uncertainty remains in the existing data that derives primarily from the lack of real-world experience involving the execution and impact of Super-ESPC delivery orders. Second, there are a number of emerging market forces, such as utility deregulation, which have the potential to significantly alter the assumptions upon which the current market assessments are based.

To ensure the accuracy and completeness of the data that FEMP will use to plan and manage its programs, our recommendations for further analysis and research are as follows:

- Reevaluate FSN (reimbursable) cash flow models based on modified delivery order goals developed by this project.

- Initiate and maintain real-time data collection of Super-ESPC project data (investment size, and annual energy and cost savings).

- Develop an on-line tracking system that summarizes project data for both on-going and completed projects on a real-time basis, and provides summary reports (total investments-todate, annual energy and dollar savings, and completed delivery orders).

- Continue survey activities in fiscal year 1999 focusing on why agencies select a given alternative financing method and why agencies select certain service packages $(\$ 10 \mathrm{~K}, \$ 30 \mathrm{~K}$, $\$ 50 \mathrm{~K}$, and customized services) from the FEMP Service Network.

- Provide assistance to the DOE Regional Support Offices in characterizing and prioritizing outreach and client sites by developing and making available detailed, region-specific, facility data (e.g., facility type, energy use, energy cost).

- Review and revise Super-ESPC delivery order goals at the 1999 FEMP Fall Meeting based on actual project data from fiscal year 1999. 


\section{DESCRIPTION OF WORK}

Original task descriptions are contained in the statement of work (Appendix B). Work on these project tasks began in mid-July, 1998. Project task work was completed on October 27, 1998 with presentations given to the FEMP Fall Meeting by each of the task managers.

Task 1 - Describe the Universe of Federal Facilities by Kate McMordie-Stoughton (PNNL)

PNNL performed a detailed characterization of Federal facilities using existing databases and completed studies. This initial task set the context for the subsequent tasks; detailing Federal facilities based on agency, region, size, facility type, energy cost, and energy use. By understanding these aspects of Federal sites, the subsequent tasks were able to characterize the ESPC market more easily. To compile the needed information, PNNL utilized the following data sources:

- FEMPTracks: facility size and type

- Annual Report to Congress FY96: agency energy use

- Commercial Building Energy Consumption and Expenditure (CBECS): facility type energy use intensity (EUI)

- Energy User News 1998 Electricity Utility Rankings: industrial electricity costs.

Important conclusions from this task are summarized in the following bullets:

- $90 \%$ of Federal floorspace and energy use is represented by the five largest agencies -Department of Defense (DOD), Department of Energy (DOE), Veterans Administration (VA), United States Postal Service (USPS), and General Services Administration (GSA). To meet the $30 \%$ reduction in overall Federal energy use by 2005 , it is crucial to concentrate on these large agencies.

- Building type is an important consideration. Sites with a high percentage of certain building use types that have high EUIs often are more appropriate for certain energy savings measures. Building types with high EUIs that are common in Federal facilities include hospitals. research and development, and lodging.

- Facility size is an important criteria. Large sites are often more appropriate for projects because the meet contract financing criteria more easily and also help to meet EPAct goals more effectively.

For a detailed description of the Task 1 findings, please see Appendix A.

\section{Task 2 - Alternative Financing Offerings in the Federal Sector by David Howard (NREL)}

This task identified agencies' policies and strategies on energy project funding. NREL described the alternative financing options both within and outside FEMP, along with the preferences of major agenctes for these options. The task detailed the following financing alternatives:

- DOE Super-ESPC 
- DOD ESPCs: Huntsville (Army) area-wide, Air Force area-wide, and Navy Caribbean indefinite delivery indefinite quantity (IDIQ)

- GSA area-wide Utility Contracts

- Utility Incentive Programs (UIP)

- Site-specific ESPC.

Table 1 summarizes the findings on individual agency preferences for alternative financing.

Table 1 Individual Agency Preferences for Alternative Financing

\begin{tabular}{|l|c|c|c|c|}
\hline Agency & DOE Super-ESPC & Huntsville ESPC & Utility Incentives & Other \\
\hline Army & $\checkmark$ & $\checkmark$ & $\checkmark$ & \\
\hline Navy & $\checkmark$ & $\checkmark$ & $\checkmark$ & \\
\hline Air Force & & $\checkmark$ & $\checkmark$ & Air Force ESPC \\
\hline GSA & $\checkmark$ & $\checkmark$ & $\checkmark$ & \\
\hline VA & $\checkmark$ & $\checkmark$ & $\checkmark$ & VISN IDIQ \\
\hline EPA & $\checkmark$ & & $\checkmark$ & Site-specific ESPC \\
\hline DOE & $\checkmark$ & & $\checkmark$ & \\
\hline NASA & $\checkmark$ & & $\checkmark$ & \\
\hline DOJ & $\checkmark$ & & $\checkmark$ & Appropriated \\
\hline USPS & $\checkmark$ & & & O\&M M funds \\
\hline DOL & $\checkmark$ & & & \\
\hline
\end{tabular}

Agency Key:

GSA: General Services Administration

VA: Veterans Administration

EPA: Environmental Protection Agency

DOE: Department of Energy

NASA: National Aeronautics and Space Administration

DOJ: Department of Justice

USPS: United States Postal Service

DOL: Department of Labor

VISN: Veterans Integrated Service Network 
For a detailed description of the Task 2 findings, please see Appendix A.

Because Tasks 3, 4, and 6 were joint activities, they are reported together following Task 5.

\section{Task 5 -- Customer Surveys by Dave Hunt (PNNL)}

PNNL obtained survey information to further assist in characterizing the Federal target market for ESPC. The surveys were designed to understand how and why decisions are made regarding the funding of energy efficiency projects. The surveys specifically addressed the financing strategies of agencies and sites, capabilities of agencies and sites, and attitudes towards the FSN concept.

PNNL conducted two surveys:

- Survey of agency energy managers: 7 responses from agencies representing $35 \%$ of civilian floorspace, which is $10.5 \%$ of the total Federal floorspace.

- Survey distributed to Federal staff at the Energy '98 conference: 57 responses from a varied group of Federal staff including energy and facility managers, engineers, and maintenance staff.

The surveys identified key issues that effect decision-making among agencies and Federal staff. Responses from the surveys concluded that mission support and operational cost savings remain the number one priority. In addition, it appears that both Super-ESPC and UIP financing options are receiving nearly equal consideration from sites. However, appropriations continue to be emphasized over the alternative financing scenarios. The surveys identified a key concern -- it is not clear if ESPCs are well understood by the target market.

For a detailed description of the Task 5 findings, please see Appendix A.

Tasks 3, 4, and 6 - Determining Delivery Order Investment Potential and Defining FEMP "Niche" Market by Andrew Nicholls (PNNL) and David Eike (PNNL)

To determine an ESPC delivery order investment and define the market for ESPC, PNNL applied information obtained in Tasks 1,2, and 5:

FEMP Workshop: Prioritizing ESPC Marketing Efforts (September 1, 1998): This workshop was a collaboration of a group of FEMP partners representing a wide spectrum of FEMP's interest. National laboratory staff, team members from the Regional Support Offices (RSO), DOE Headquarters and field staff, and energy managers from the Department of Commerce and the General Services Administration attended the workshop. This group discussed various aspects of the FEMP Super-ESPC Delivery Order goals and identified key criteria that are crucial when identifying and targeting potential sites for ESPC projects. Workshop participants actively developed the list below at the workshop, representing a consensus listing of criteria (in rank order) to be applied in identifying and prioritizing sites for outreach efforts:

1. Site energy use intensity

2. Total agency gross square foot

3. Agency support for energy efficiency

4. Regional concentrations of agency sites combined with a tailored marketing approach

5. Transactions cost of marketing. 
Super-ESPC Delivery Order Goal: The original delivery order goal for Super-ESPCs set by FEMP was considered very aggressive by the attendees of the FEMP Spring Meeting. Therefore, a main objective of this task was to develop a delivery order goal that considered other project financing options available and the Federal building inventory. PNNL analyzed the Super-ESPC market, taking into account the estimated market share of other alternative financing options, such as the Huntsville ESPC and utility incentive programs (UIP). The task assimilated the information provided in the preceding tasks (Federal facilities data, customer surveys, the September 1 workshop results, and financing preferences of agencies) to help build the foundation to estimate the target goal.

To accomplish this task, PNNL developed a PC-based accounting tool to calculate delivery orders based on agencies estimated market shares between the following financing options: FEMP Services Network - DOE Super-ESPC, UIPs, Army Corps of Engineers region-wide ESPC (Huntsville), and "Other" category. The baseline data for each agency's energy consumption and total square-footage were based on FEMP's Annual Report to Congress FY96. The tool weighted each agency's estimated market share by its total square-footage. The original market share assumptions were correlated from the September 1 FEMP Workshop and Task 2 (the task that analyzed agencies' alternative financing preferences). From this information, the accounting tool calculated the amount of energy savings required to reach the EPAct reduction goals of $30 \%$ by 2005 .

PNNL made several "best-guess" assumptions, based on the best available information at the time of the analysis to calculate the delivery orders:

- Estimate of the Super-ESPC market share of total energy savings along with market share of other financing options (see Tables 2 and 3 for market share estimates).

- 15,000 Btus saved per dollar invested (Btu saved/\$) “effectiveness" multiplier

- $\$ 1.5$ million average delivery order size.

The estimated market shares for this scenario are detailed below in Table 2. These initial market shares represent a possible scenario and should not be construed as a definitive statement. This is because the Super-ESPC is a fairly new option to the "alternative financing market" and information on the other options is also not readily available.

The tool calculated the total investment required to reach the 2005 goal by dividing the total government-wide required energy savings (Btu) by the "effectiveness multiplier" (Btu saved/\$). The tool then divided this value by the average delivery order size $(\$ / D O)$ to estimate the total number of delivery orders necessary to meet the target. This resulted in an estimated delivery order goal of 678 with a total capital investment of $\$ 1.03$ billion. This capital investment figure was calculated by multiplying the Super-ESPC market share ( $27 \%$ for this scenario) by the Government Performance \& Results Act (GPRA) value of $\$ 3.8$ billion -- this is the total capital investment required to reach EPAct goals by 2005 . Also, the Super-ESPC capital investment can be calculated simply by multiplying the number of delivery orders (678) by the cost per delivery order ( $\$ 1.5$ million), which comes out to a similar figure of $\$ 1.02$ billion of required investment. 
Table 2. Market Share for Alternative Financing Options-- Workshop Scenario

\begin{tabular}{|l|r|r|r|r|}
\hline Agency & $\begin{array}{c}\text { DOE Super-ESPC, } \\
\%\end{array}$ & $\begin{array}{c}\text { Utility Incentives, } \\
\%\end{array}$ & $\begin{array}{c}\text { Huntsville ESPC, } \\
\%\end{array}$ & $\begin{array}{c}\text { Other, } \\
\%\end{array}$ \\
\hline Army & 10 & 0 & 90 & 0 \\
\hline Air Force & 0 & 0 & 100 & 0 \\
\hline Navy & 40 & 10 & 50 & 0 \\
\hline VA & 40 & 20 & 40 & 0 \\
\hline DOE & 100 & 0 & 0 & 0 \\
\hline USPS & 20 & 0 & 0 & 80 \\
\hline GSA & 40 & 60 & 0 & 0 \\
\hline Marine Corps & 30 & 40 & 0 & 30 \\
\hline HHS* & 100 & 0 & 0 & 0 \\
\hline NASA & 100 & 0 & 0 & 0 \\
\hline DOI* & 100 & 0 & 0 & 0 \\
\hline EPA & 100 & 0 & 0 & 0 \\
\hline DOL & 60 & 20 & 20 & 0 \\
\hline Other & 77 & 4 & 19 & 0 \\
\hline Total Market & 27 & 8 & 56 & 9 \\
Share & & & & 9 \\
\hline
\end{tabular}

*HHS = Health \& Human Services; DOI = Department of Interior. All other acronyms were previously defined in Table 1.

FEMP FY 1999 Fall Meeting (Arlington, VA: October 27, 1998): A briefing of the market analysis was made at the 1998 Fall FEMP Meeting, which included staff from DOE Headquarters, DOE RSOs, and national laboratory staff. The results, assumption, and underlying accounting tool were discussed and demonstrated for the first time at this meeting. As expected and desired, a significant discussion resulted because several participants felt that DOE Super-ESPC market share and Huntsville share were overestimated, while the utility investment share was underestimated. Therefore, during a working lunch, Lou Harris of FEMP, Mary Colvin of NREL, and other participants interactively developed a new scenario that used VERY different market shares and emphasized utility investments. The market shares for this scenario are detailed below in the Table 3.

Using these assumptions for each alternative financing option (by agency), the tool calculated a total of 452 delivery orders, with an associated capital investment of $\$ 678$ million, need to be completed by the FSN between 1999 and 2005 to meet EPAct goals. The estimated capital investment resulting from utility investments increased from $\$ 300$ million to $\$ 1.41$ billion.

For more details on these tasks, please see the Appendices A and B. 
Table 3. Market Share for Alternative Financing Options - Utility Emphasis

\begin{tabular}{|l|r|r|r|r|}
\hline Agency & $\begin{array}{c}\text { DOE Super-ESPC, } \\
\%\end{array}$ & $\begin{array}{c}\text { Utility Incentives, } \\
\%\end{array}$ & $\begin{array}{c}\text { Huntsville ESPC, } \\
\%\end{array}$ & $\begin{array}{c}\text { Other, } \\
\%\end{array}$ \\
\hline Army & 10 & 30 & 60 & 0 \\
\hline Air Force & 0 & 25 & 75 & 0 \\
\hline Navy & 30 & 30 & 40 & 0 \\
\hline VA & 33 & 33 & 33 & 0 \\
\hline DOE & 70 & 30 & 0 & 0 \\
\hline USPS & 0 & 80 & 0 & 20 \\
\hline GSA & 10 & 70 & 0 & 20 \\
\hline Marine Corps & 20 & 60 & 20 & 0 \\
\hline HHS & 75 & 25 & 0 & 0 \\
\hline NASA & 80 & 20 & 0 & 0 \\
\hline DOI & 70 & 30 & 0 & 0 \\
\hline EPA & 100 & 0 & 0 & 0 \\
\hline DOL & 60 & 40 & 0 & 0 \\
\hline Other & 29 & 58 & 13 & 0 \\
\hline Total Market & 18 & 37 & 41 & 4 \\
Share & & & & \\
\hline
\end{tabular}




\section{OUTSWE REVIEW}

\section{FSN Coordinating Council (October 29, 1998)}

The day after the FEMP Fall Meeting, the FSN Coordinating Council met to discuss pertinent issues facing the FSN. Some of the participants expressed concern about the significant reduction in the delivery order goal, which resulted from the new analysis. Suggestions were made that real field data be collected on the critical energy saved per dollar invested (Btu saved/\$) from FEMP's Regional Support Offices. Multipliers from two regions were found to be $13,500 \mathrm{Btu}$ saved $/ \$$ and $14,200 \mathrm{Btu}$ saved/\$. Data from the other four regions were not available. Therefore, the recommendation is that the projections should focus on the $15,000 \mathrm{Btu}$ saved/\$ multiplier.

\section{Arthur D. Little Report: A Review of Supporting Analysis for FEMP's Super-ESPC Program}

Oak Ridge National Laboratory contracted with Arthur D. Little to review the ESPC Business Strategy Development. At the time this letter report was written (December 1998), Arthur D. Little had developed a draft report, summarizing its initial findings. This draft report assessed the procedures, assumptions, and results of each task and gave recommendations for further research. The final version of the Arthur D. Little report "A Review of Supporting Analysis for FEMP's Super-ESPC Program" was issued in August 1999. The findings contained in this final version were in agreement with the draft findings mentioned in this text.

In general, the report concluded that additional data and analysis are needed to develop more accurate delivery order goals and to guide the activities of the FSN in marketing the Super-ESPC program. The report did not dispute the overall approach, findings, and recommendations of the original analysis, but identified specific areas where improvements and enhancements could be made. The report is based on documents and presentations from the FEMP FY 1999 Fall Meeting held on October 27, 1998.

Documents and information provided by FEMP, PNNL and DOE staff was also used to support this report.

\section{Appendices}

The following documents are found in Appendix A and B.

1. Task 0 Presentation: An overview of the project presented at the FEMP FY 1999 Fall Meeting. (Appendix A - page A.1)

2. Task 1 Presentation: Summary of Task 1 findings which describes the Universe of Federal Facilities. (Appendix A - page A.9)

3. Task 2 Presentation: Summary of Task 2 findings -- Alternative Financing Offerings in the Federal Sector (Appendix A - page A.15)

4. Task 5 Presentation: Slides summarizing findings of Task 5 -- Customer Surveys (Appendix A - page A.19)

5. Task 3, 4, and 6: Summary of findings of Tasks 3, 4, and 6 -- Determining Delivery Order Investment Potential and Defining FEMP "Niche" Market (Appendix A - page A.31) 
6. Statement of Work: The original statement of work detailing the description of work, objectives, and background. (Appendix B - page B.1)

7. Energy 98 Survey Results: Summary of the survey results from the Energy ' 98 Survey as part of Task 5 (Appendix B - page B.5)

8. Energy Manager Survey: Survey that was distributed to Energy Managers as part of Task 5. (Appendix B - page B.7)

9. September 1 Selection Criteria: Word Perfect file summarizing the selection criteria that was produced at the September $1^{\text {st }}$ FEMP Workshop as part of Tasks 3, 4, \&6 (Appendix B - page B.10). 
APPENDIX A

October 27, 1998 Power Point Presentations 


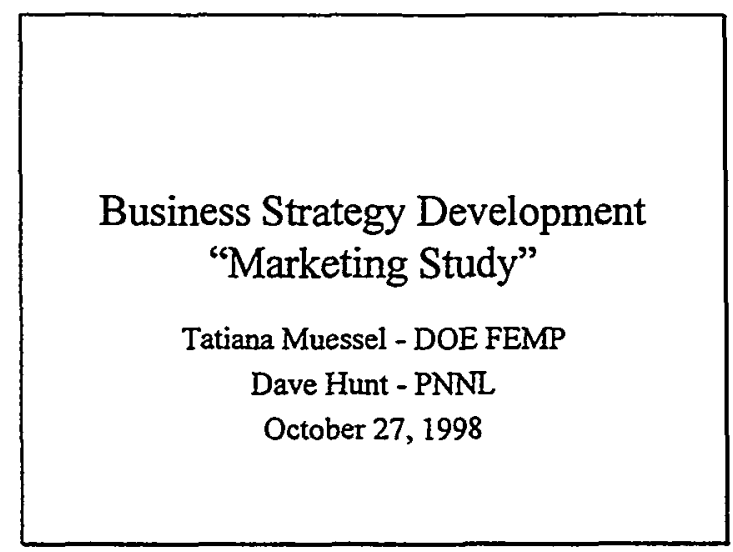

\section{Session Objectives}

- Develop understanding of federal market for Super-ESPC delivery orders

- Identify FEMP FSN delivery order "targets"

- Identify factors impacting FSN and outreach efforts 


\section{Results}

- Define federal project playing field - who, what, why, and how much.

- Potential impacts:

- Modified delivery order targets for FSN and RSOs?

- Information for outreach strategy

- FSN and FEMP planning and budget reassessments?

\section{Problem Statement Number 1}

- The FEMP/FSN reimbursable model employs a series of assumptions to project a business volume. Are the assumptions regarding the number of sites, number of delivery orders, capital investment volume, and average project size reasonable? 


\section{Problem Statement Number 2}

- The RSOs/REAPs have limited resources available to market services. Are there outreach strategies that will assist the REAPs in more effectively utilizing scarce resources?

\section{Background - Objective}

"To develop a detailed understanding of the federal market for Super-ESPC delivery orders. This understanding will assist FEMP in defining the market, assessing its role in that market, segmenting the market, and differentiating its approach to those segments. The analysis should allow more efficient assessment of resources required to service the FEMP "niche," and improve the efficiency and allocation of those resources, thus providing insight into how the FSN can be an effective agent for ESPC delivery orders." 


\section{Background - Resources}

- Limited budget

- Limited time

- Lab staff

- Stakeholder interest

\section{Task Descriptions}

- Task 1 - Describe the universe of federal facilities

- Task 2 -- Identify other available financing alternatives AND summarize agency investment programs, policies, and projections

- Task 3 -- Identify tentative FSN SuperESPC target market and estimate market share 


\section{Task Descriptions - Continued}

- Task 4 -- Develop resource requirements analysis

- Task 5 -- Survey customers in tentative target market

- Task 6 -- Redefine target market and identify FEMP "niche" market

- Task 7 -- Define strategy to reach targeted customers

\section{Presentation Outline}

- "The Universe of Federal Buildings" by Kate McMordie-Stoughton (PNNL)

- Overview of Alternative Financing Offerings in the Federal Sector by Dave Howard (NREL)

- "Customer Surveys" by Dave Hunt (PNNL)

- "Target Markets and Delivery Order Goals" by Andrew Nicholls (PNNL)

- Strategy to Reach Targeted Customers by Tatiana Muessel (DOE FEMP) 
Go to slides for individual briefing packages

Task 7:

Reaching Targeted Customers

- Available outreach resources

- Tailored products

- Outreach and communication plan impacts

- Impacts on FSN?

- project flow

- cash flows

- staffing levels 


\section{Recommendations}

- Revise FSN DO and regional targets and reevaluate FSN cash flow models

- Regions should prioritize sites for outreach

- Integrate utility financing and technical assistance services into the FSN

\section{Issues}

- Goal of FSN -- energy/dollar savings or DOs?

- ESPC or utility financing?

- FEMP or COE or other as provider?

- Prioritization of Sites - needed? Doable?

- New targets - what are impacts on RSOs?

- What additional data are required? 
A. 8 


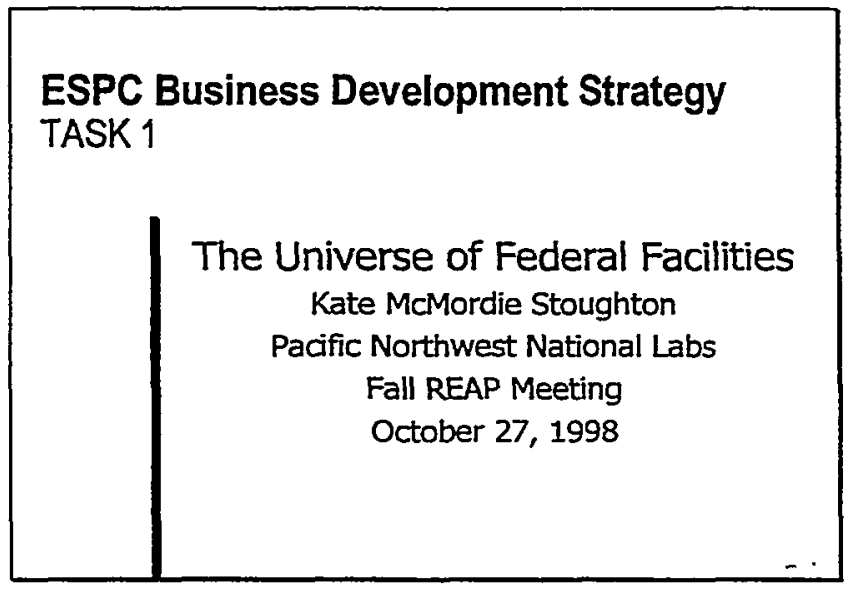

What will be covered:

Universe of Federal facilities:

- energy consumption by agency

- regional data

- size of faclilities

- type of faclities

- energy use intensity and costs

Data Sources:

- FEMPTracks

- Annual Report to Congress FY96

- Commerdal Buildings Energy Consumption and Expenditures (CBECS)

- Energy User News -- Industrial Energy Rates 


\section{Total Federal Floorspace Breakout}

Annual Report to Congress FY 96

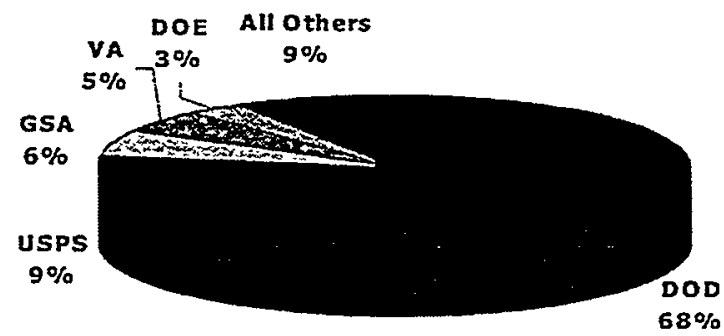

\section{Total Federal Energy Breakout} Building and Facility Net Energy Use

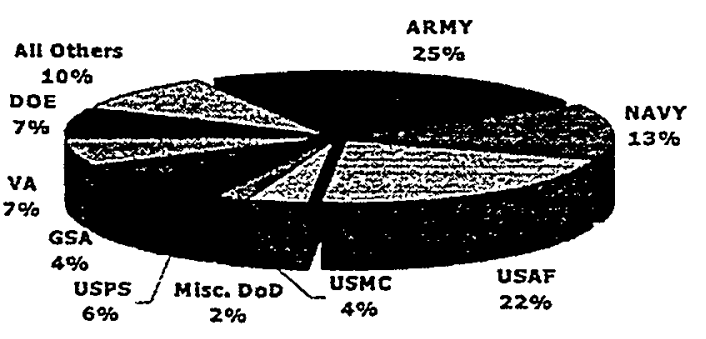




\section{Federal Facilities in the USA}

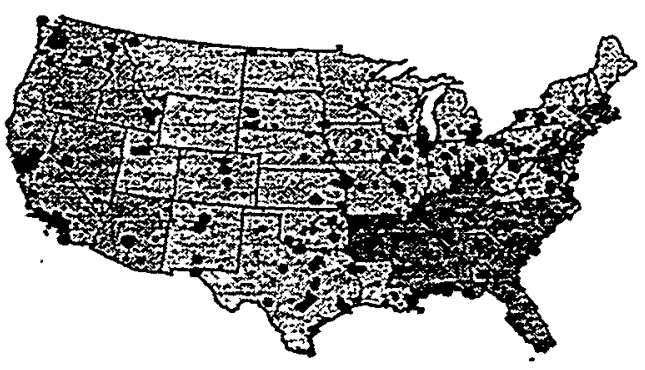

\section{Civilian Facility Type Breakout}

FEMPTracks

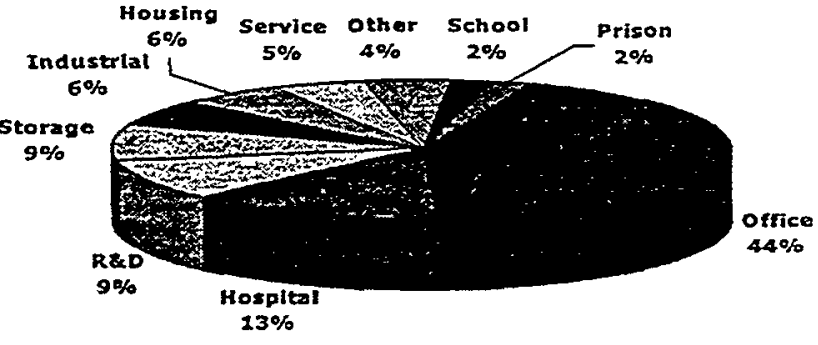



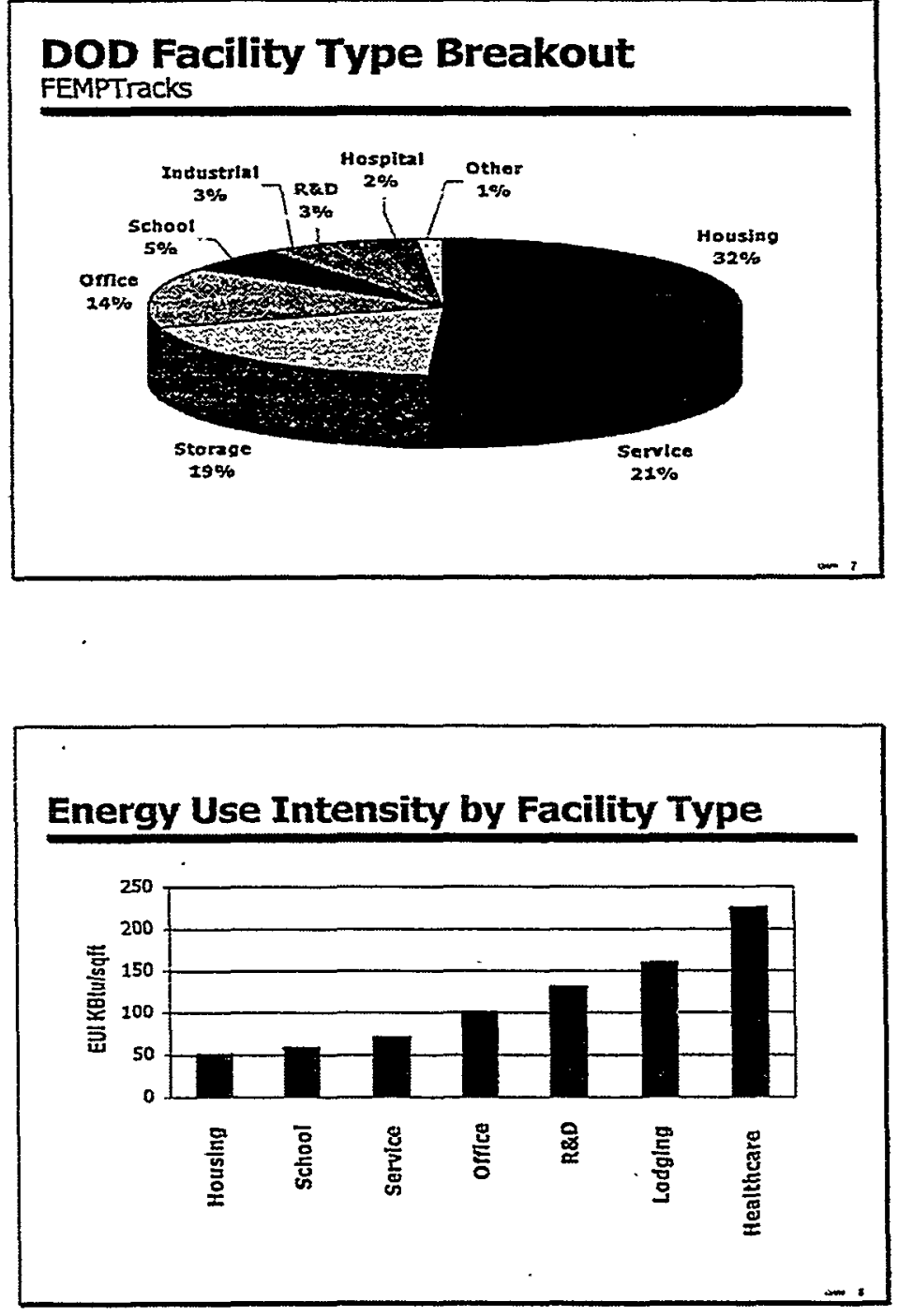


\section{"Hunt" Curve}

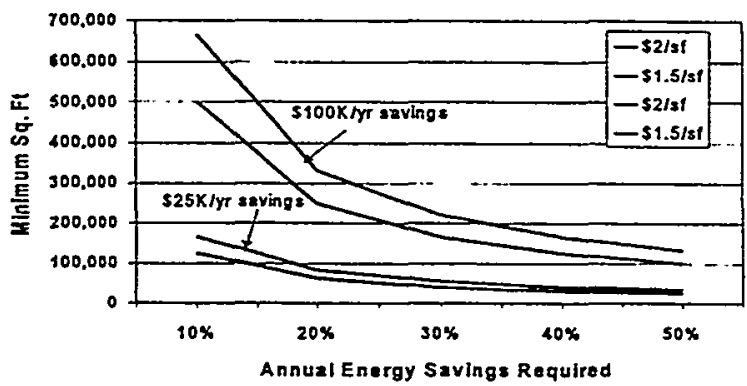

\section{Electric Energy Cost Ranking Top 10 most expensive states}

\begin{tabular}{|c|c|c|c|c|}
\hline State & $\begin{array}{c}\text { Industrial } \\
\text { Elec. } \\
\text { (\&/KW h) }\end{array}$ & $\begin{array}{l}\text { Electricity } \\
\text { Cost Rank }\end{array}$ & $\begin{array}{c}\text { State Stze } \\
\text { Rank }\end{array}$ & Region \\
\hline Hawait & 10.33 & $T$ & 72 & 6 \\
\hline New flampshire & 9.19 & 2 & 46 & I \\
\hline Rhodelsliand & 9.06 & 3 & 39 & $T$ \\
\hline Massachusetts & 8.60 & 4 & $T 7$ & $T$ \\
\hline Connecticut & 8.47 & 5 & 40 & $T$ \\
\hline New Jersey & 8.39 & 6 & 78 & 2 \\
\hline Vermont & 7.32 & 7 & 51 & $T$ \\
\hline Califomia & 3.23 & 8 & $T$ & 6 \\
\hline Maine & 6.69 & 9 & 45 & $T$ \\
\hline New York & 6.50 & TO & 3 & $T$ \\
\hline
\end{tabular}

Energy User News: Ave. Industrial Rates 


\section{Conclusions}

. 90\% of Federal Floorspace and Energy are consumed by 5 AGENCIES:

DOD, DOE, VA, USPS, \& GSA

- Facility Type

- agencies which have facility types with high EUI suggest larger savings potential

Hospital, R\&D, and Lodging

\section{Conclusions (cont..)}

- Facility Size

- larger sites have a bigger impact on meeting EPAct goals

- larger sites may meet contract needs more easily

* Energy Cost

- high energy cost yield lower paybacks 
Task 2 Power Point Presentation

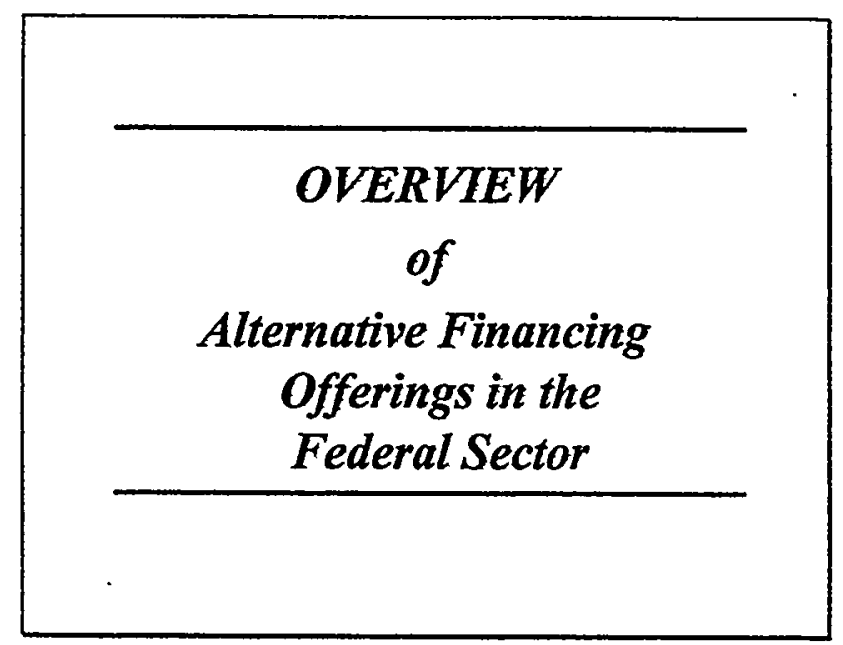

\begin{tabular}{|l|} 
Routes Available for Implementing Projects \\
\hline \\
a DOE Super ESPC \\
$\square$ DOD ESPC Programs \\
- Huntsville Areawide ESPC \\
- Air Force Areawide ESPC \\
- Navy Caribbean IDIQ \\
ם GSA Areawide Utility Contracts \\
o Individual Utility Contracts \\
व Site Specific ESPC \\
\end{tabular}

A. 15 


\section{ESPC IDIQ PROVIDERS}

\begin{tabular}{|l|l|}
\hline Provider & \multicolumn{1}{|c|}{ Customers Targeted } \\
\hline Huntsville & All federal and state facilities \\
\hline Air Force & $\begin{array}{l}\text { Air Force bases in the continental } \\
\text { United States }\end{array}$ \\
\hline Navy & $\begin{array}{l}\text { Navy and Marine facilities in the } \\
\text { Caribbean Ocean }\end{array}$ \\
\hline
\end{tabular}

All Aconcios May Stal Use Sito Specific ESPC: This only compares IDiO Contracts

\begin{tabular}{|l|l|}
\hline \multicolumn{2}{|c|}{ Utility Project Providers } \\
\hline Provider & Comments \\
\hline $\begin{array}{l}\text { Local } \\
\text { Utility }\end{array}$ & Depends on the policies of the local utility \\
\hline $\begin{array}{l}\text { GSA } \\
\text { Areawide } \\
\text { Utility } \\
\text { Contracts }\end{array}$ & $\begin{array}{l}\text { Have taken advantage of electric deregulation in } \\
\text { negotiating in DSM services in Northeast electric }\end{array}$ \\
\hline
\end{tabular}

All Agencies Mar SIFIUse Sie Specific ESPCS This conly compares loie Contracts 


\section{DOE Super ESPC Prospects}

\begin{tabular}{|c|c|c|}
\hline Agency & Financing Alternatives & Super Comments \\
\hline Army & $\begin{array}{l}\text { Huntsville Areawide } \\
\text { Utility } \\
\text { Major Command IDIQ } \\
\text { DOE Supers }\end{array}$ & $\begin{array}{l}\text { Limited possibility } \\
\text { for DOE Super, and } \\
\text { FSN tech support } \\
\text { to utility projects }\end{array}$ \\
\hline Navy & $\begin{array}{l}\text { DOE Supers } \\
\text { Huntsville Areawide }\end{array}$ & \\
\hline Air Force & $\begin{array}{l}\text { Huntsville Areawide } \\
\text { Air Force Regional } \\
\text { Utility }\end{array}$ & $\begin{array}{l}\text { Will not use Supers } \\
\text { do to perceived } \\
\text { Economy Act } \\
\text { conflict }\end{array}$ \\
\hline
\end{tabular}

\section{DOE Super ESPC Prospects}

\begin{tabular}{|l|l|l|}
\hline Agency & Financing Alternatives & Super Comments \\
\hline GSA & $\begin{array}{l}\text { Utility } \\
\text { DOE Supers } \\
\text { Huntsville Areawide }\end{array}$ & $\begin{array}{l}\text { Possibility for DOE } \\
\text { Super, and FSN } \\
\text { tech support to } \\
\text { utility projects }\end{array}$ \\
\hline VA & $\begin{array}{l}\text { DOE Supers } \\
\text { Huntsville Areawide } \\
\text { VISN-wide IDIQ } \\
\text { Utility }\end{array}$ & Institute by VISN \\
\hline EPA & $\begin{array}{l}\text { DOE Supers } \\
\text { Utility } \\
\text { Site specific }\end{array}$ \\
\hline
\end{tabular}




\section{DOE Super ESPC Prospects}

\begin{tabular}{|l|l|l|}
\hline Agency & Financing Alternatives & Super Comments \\
\hline DOE & $\begin{array}{l}\text { DOE Supers } \\
\text { Utility }\end{array}$ & \\
\hline NASA & $\begin{array}{l}\text { DOE Supers } \\
\text { Utility }\end{array}$ & $\begin{array}{l}\text { Willing to consider } \\
\text { leading edge } \\
\text { technologies } \\
\text { outside walls }\end{array}$ \\
\hline $\begin{array}{l}\text { Department } \\
\text { of Justice } \\
\text { Bureau of } \\
\text { Prisons) }\end{array}$ & $\begin{array}{l}\text { DOE Supers } \\
\text { Appropriated Funds }\end{array}$ \\
\hline
\end{tabular}

\section{DOE Super ESPC Prospects}

\begin{tabular}{|l|l|l|}
\hline Agency & Financing Altematives & Super Comments \\
\hline USPS & $\begin{array}{l}\text { Utility } \\
\text { O\&M Funds }\end{array}$ & $\begin{array}{l}\text { Are considering use } \\
\text { of Supers, under } \\
\text { special conditions. } \\
\text { Have their own } \\
\text { procurement rules } \\
\text { and funds }\end{array}$ \\
\hline DOL & $\begin{array}{l}\text { Utility } \\
\text { DOE Supers }\end{array}$ & $\begin{array}{l}\text { Will bundle by Job } \\
\text { Corps Region. } \\
\text { Four future projects } \\
\text { identified. Will try } \\
\text { to do one or two } \\
\text { projects per year. }\end{array}$ \\
\hline
\end{tabular}




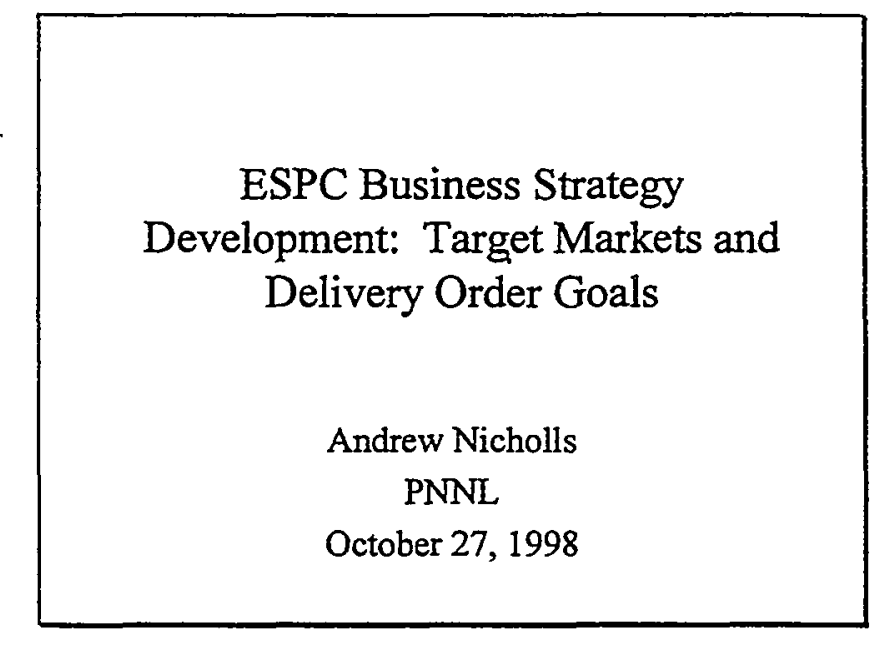

\section{Outline}

- Overview of Tasks 3, 4, 6

- Sept. I Workshop Results/Issues

- Importance of Tasks 1, 2, 5

- Government Performance \& Results Act

-Who gets what: sharing of the efficiency market by Agency

- Revised Delivery Order Goals through 2005 


\section{Guiding Principles}

- Develop paths from here to 2005

- Not absolute precision, but capture general trend/direction

- Perfect information perfectly unavailable

- Develop plausible scenarios of what may happen, not a forecast of what will happen

- Must "pass" peer-review test

\section{Business Development Tasks I}

- Task 1: Describe universe of Federal buildings

- Task 2: Identify alternative financing offerings

- Task 3: Identify key markets and market shares for FEMP ESPC and develop tentative Delivery Order goals through 2005 


\section{Business Development Tasks II}

- Task 4: Identify different delivery order patterns for achieving goal/analyze resource implications

- Task 5: Survey Federal Customers in Market

- Task 6: Revise target markets/delivery order goals per Task 5 \& other market intelligence

\section{Business Development Tasks}

\section{III}

- Task 7: Define Strategy to reach targeted customers 


\section{Sept.1 Workshop}

- What? Define and segment market for FEMP Super and Technical ESPC Delivery Orders.

- Who? Small number of folks from REAPs, Federal Agencies (GSA, Commerce),

FEMP, National Laboratories

\section{Sept.1 Workshop II}

- Agenda?

-Findings on buildings universe

- Findings on alternative offerings

- Round-the-room participant input

- Principal markets?

- FSN Focus?

- Weave the Threads: Consensus on markets and priorities 

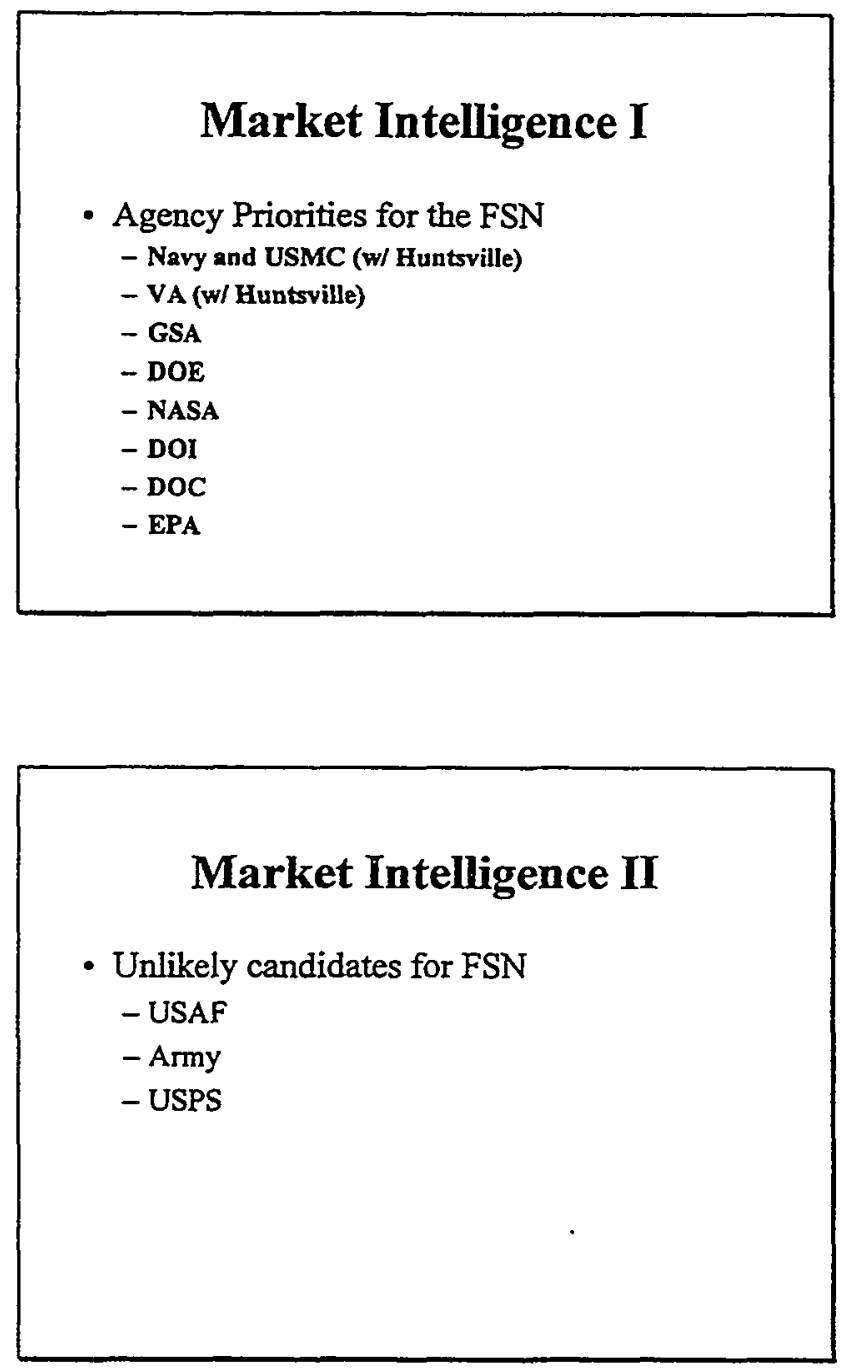


\section{Market Intelligence III}

- Insight from you? Big civilian agencies we didn't discuss

- HHS ( $5.5 \%$ Civ. Total)

- USDA ( $2 \%$ Civ. Total)

- DOT ( $3 \%$ Civ. Total)

\section{Selected Workshop Issues}

- Data availability inhibits ability to draw "firm" conclusions - caveat emptor!

- Need to answer the aggregation question

- The early bird gets the worm

- Placing Delivery Orders takes long time contract personnel bogged down

- Need more RSO personnel 


\section{Selected Workshop Issues II}

- Energy not an agency priority

- Synergy: Link efficiency to capital upgrades strategy for success

- Leasing ups complexity for ESCO projects

- How much marketing are ESCO's doing on own?

- Winning GSA key: most agencies rent space from it

\section{Workshop: FSN Roles}

- Unique role in promoting renewables, new technologies, systems approach

- Central collection point for marketing data, field experience, success stories

- Provider of technical info to RSO's . via national labs 


\section{Workshop: FSN Roles II}

- Provider of marketing intelligence to RSO's

- Serve as conduit for full suite of FEMP activities, e.g. audits - not just ESPC's

- Develop reimbursable stream for FEMP

\section{Selection Criteria for Prioritizing} REAP Marketing Resources

- Top Three

- Site energy intensity: Btu/GSF

- Total agency GSF

- Agency support for efficiency?

- Next Three

- Regional concentrations of agency sites

- Transactions cost of marketing

- Agency plans for space in future 


\section{Government Performance \& Results Act}

- Requires all agencies to submit measurable goals and performance measures with budget request

- Performance measures subject to audit

- Bottom line: develop defensible, credible pathway from current activities to future goals

\section{GPRA \& FEMP}

- To reach year 2005 goal, federal facilities will need to reduce energy use by 57 Trillion Btu (site) per year - a 17\% reduction

- Equivalent to Nevada's homes foregoing energy services entirely

- That will require $\$ 3.8-5.0$ Billion of total investment capital, through 2005 


\section{GPRA \& FEMP II}

- How much of that investment total will be directly attributable to Super and Technical ESPC delivery orders?

- How much attributable to Utility Financing?

- How many delivery orders will be placed in FY99? FY2000?

\section{Approach}

- Develop market shares for FSN, Huntsville, Utility Financing, "Other" by individual agency/service

- Task 2 market intelligence

- Workshop intelligence

- Task 5 survey information

- Conversations with FEMP staff 


\section{Approach II}

- Weight shares by agency's 1996 energy use

- Sum across agencies to develop FSN share of \$3.8 Billion investment

- Calculate required delivery orders needed to generate capital - in total, per year, and by region

\section{Results: "Workshop" Scenario}

- ESPC Investment Capital Needed: \$1.1 Billion (About equal to M. Carr estimate)

- Total Delivery Orders: 754 @ \$1.5M/D.O.

- Delivery Orders per Year: 126

- Pro-rate by regional share of GSF:

- Philly 34 D.O./year or $\$ 51 \mathrm{M} /$ year

- Boston $4 /$ year or $\$ 6 \mathrm{M} /$ year

- Everyone else: about 22/year or \$33M/year 


\section{Establishing Regional Priorities}

- Agency priorities and policies

- Internal champion?

- How big in region?

- Actual site characteristics

- Intensity

- Total GSF

- Aggressive competitors?

- Personnel availability 
Task 5 Power Point Presentation

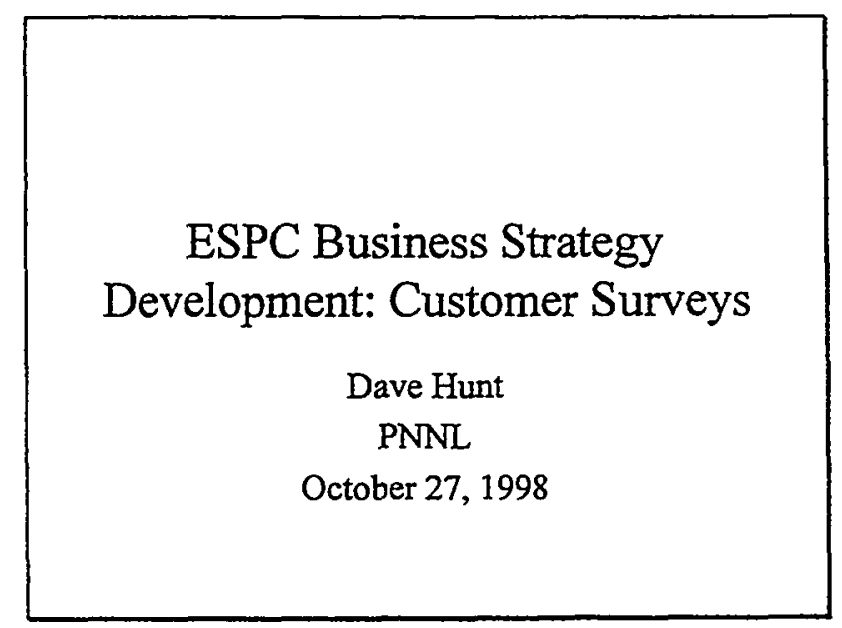

\section{Task Objective}

- Obtain customer information to further assist in characterizing federal target market:

- Decision makers

- Decision bases

- Site and agency financing strategies

- Site and agency capabilities

- Attitudes on FSN concept 


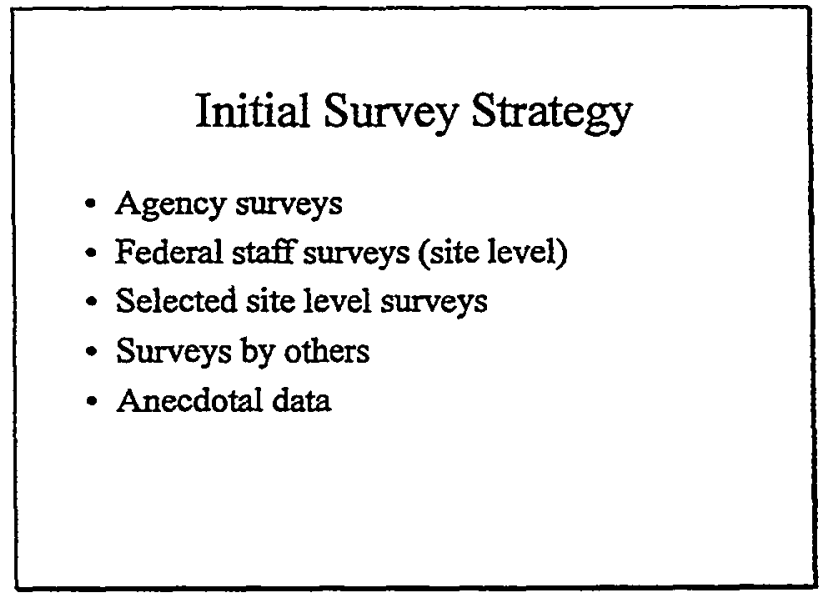

\section{Agency Surveys}

- To understand agency strategies, processes, and resources

- Results: Helpful but ...

-7 responses

$-34.7 \%$ civilian floor space covered

$-10.5 \%$ federal floor space covered 


\section{Federal Staff Surveys}

- Identify site energy management priorities, strategies, and capabilities

- Results:

- 57 responses

- Priorities are operational $\$$ savings and mission support

- ESPC and utility financing receiving equal consideration

- Majority of sites feel technically qualified

- Still cmphasize appropriations, O\&M, and awareness

\section{Surveys by Others}

- Alliance to Save Energy

- "A Survey of DOD Facility Energy Management Capabilities" (MR-875-OSD) by Rand (www.rand.org/publications/electronic/)

- E Source Strategic Memo SM-98-3, "Corporate Energy Managers Express Their Views in Third Annual E Source Survey" 


\section{Anecdotal Data}

- Utility project investments - per 40 reporting utilities:

- \$300M+ in anticipated, proposed, underway, or completed projects

$-\$ 1.6 \mathrm{M}$ average project cost

- GSA regional energy manager meeting agency is relying on utility investments

- Energy '98 conversations and presentations

\section{Conclusions}

- Equal consideration between ESPC and utility financing options

- Question if ESPC is understood by the target market 
APPENDIX B

Miscellaneous Documents 


\section{Statement of Work \\ ESPC Business Strategy Development}

\section{Objective of Business Strategy Development}

To develop a detailed understanding of the Federal market for Super ESPC and Technology ESPC delivery orders. This understanding will assist FEMP in defining the market, assessing its role in that market, segmenting the market, and differentiating its approach to those segments. The analysis should allow more efficient assessment of resources required to service the FEMP "niche," and improve the efficiency and allocation of those resources, thus providing insight into how the FEMP Service Network (FSN) can be an effective agent for ESPC delivery orders.

\section{Overview of Approach}

1. Describe the universe of buildings/facilities and savings potentials

2. Identify and describe alternative project financing offerings in the federal sector

3. Determine FEMP ESPC delivery order goals and estimate market share/tentative target market

4. Conduct resource/scenario requirements analysis

5. Conduct survey of customers in tentative target market and identify continuing barriers

6. Refine definition of target market/define and describe FEMP 'niche' market

7. Define strategy to reach targeted customers; identify needed barrier reduction actions

\section{Description of Tasks}

1. Describe the universe of buildings/facilities. Using existing databases and completed studies, such as FEMPTracks and CBECS, as well as information being gathered for other purposes, such as by the FEMP Utility Program, develop a detailed characterization of the federal buildings market that delineates and describes sub-markets in terms of a variety of attributes. Examples include parent agency (and "sub-agency" where appropriate), region, age, square feet, type/function of building (warehouse, lab, etc), (estimated) energy use, energy costs, recent energy efficiency projects, energy savings potential, status of electric utility deregulation, etc. The Task 1 lead will work with the Task 3 lead to identify data searches and data sorts necessary to support Task 3 activities.

2. Identify and describe alternative project financing offerings in the federal sector. Identify other programs, both within and outside FEMP, that make available alternatives for agencies' energy savings investments and resources, both ESPC and other (e.g., Army Corps of Engineers, Bonneville Power, FEMP Utility Service Program, etc). Describe the subsets of agencies and facilities that are likely to use these programs, and estimate the amount of capital investment (and energy and dollar savings) likely to come from these activities. Also summarize agency policies and strategies on energy project funding. One outcome of this task will be the identification who else is offering energy project financing services to federal agencies and how much investment, energy, and cost savings will result from their efforts. A second outcome of this task will be a summary of current agency energy project investment programs, policies, goals, and projections. The Task 2 lead will work with the Task 3 lead to identify specific issues and data necessary to support Task 3 activities.

3. Determine FEMP ESPC delivery order goals and estimate market share/tentative target market. Based on the results of Tasks 1 and 2, this task makes a first cut calculation on how 
much energy savings would need to be generated by FEMP Super-ESPCs and what the size and nature of the FEMP Super-ESPC market is likely to be, recognizing other efforts (e.g. Army Super ESPC) and the goals and policies of individual agencies. Thus, the investment levels calculated in Task 2, plus the FEMP Super- ESPC market would together represent the total capital investment that the federal government would need to make to achieve the 2005 goal. As a part of this task, a small "workshop" will be convened in Washington, DC. Workshop invites will be those individuals identified by the FEMP manager and the project manager as members of the project support coalition (i.e., selected FEMP regional staff, FEMP Service Network principals, national laboratory leads, and selected agency energy managers). This workshop will allow for the coalition members to provide input into the market share estimating process. The Task 3 manager will assist the Task 1 and 2 managers in their initial planning efforts by identifying data types and/or formats that are of particular interest toward the completion of Task 3.

4. Conduct resource/scenario requirements analysis. Using a process similar to that used at the 1998 Spring Meeting Planning-Budgeting Workshop, identify alternative delivery order patterns for achieving the goal formulated in Task 3 , and analyze the resource requirements for those patterns.

5. Conduct survey of customers in tentative target market. Obtain detailed information about the tentatively identified customer set, through some sort of survey process. The scope of new survey efforts would be determined based on schedule and other task requirements, but examples of topics that could be covered are: Who are the customers, i.e., in an agency who makes the DO decision? What other priorities do those customers have that might compete with energy ESPC? What are those customers attitudes towards a business like this? What are the agency's plans for the facility - expand, consolidate, close? Price sensitivity -- how important is the price of the service to the target market? Also identify and analyze other performance-related conditions and constraints that may impact agency decisions to place Super-ESPC delivery orders, such as contracting and procurement regulations, deferred revenue requirements, FEMP and other agencies' budget limitations, etc. The Task 5 task manager will work with the Task 6 task manager to identify specific survey information needed in support of Task 6 .

6. Refine definition of target market/define and describe FEMP 'niche' market. Based on the outcome of Task 5, define the FEMP Super-ESPC target market, and reassess the energy savings and investment likely to come from this market. Is this market large enough to achieve the energy investment goal identified in Task 3 ?

7. Define strategy to reach targeted customers. This step begins to formulate a delivery order attainment strategy based on the results of the previous steps --especially the Step 4 resource and scenario analysis and Task 6, the definition and description of the FEMIP market. Among the kinds of issues that would be addressed are: is the delivery order investment goal achievement feasible, given what we know about resource availability? Given what we now know about our customers, how can we modify the program to increase their enthusiasm and receptivity for ESPC? What kinds of process improvements are possible to better meet customer needs? What are the most effective targeting activities for the REAP teams?

What is the best way to prioritize potential customers, for example, should we request that the President direct Agencies to prioritize their sites? Much of the work in this task is to be completed as part of the FEMP Fall Meeting, allowing for wider participation and consensus building in the resulting business strategy. 


\section{Project Management}

Roles and Responsibilities. The work will be managed by Pacific Northwest National Laboratory, under the overall direction of FEMP's Jerry Dion and Tatiana Muessel. Dave Hunt, at PNNL-BWO will be the project manager, employing a collaborative approach that utilizes input, expertise, and existing data from other parts of FEMP, the FSN, Golden Field Office, REAP teams, and other laboratories. Other PNNL staff will contribute to the project as needed.

Schedule and Scope. At the Spring Meeting there was general agreement that there is a high need to conduct this kind of work as quickly as possible. Therefore, Tasks 1-6 will be completed during fiscal year 1998, and Task 7 will be completed immediately following the Fall Meeting which is scheduled for October. It is known that others in the FEMP family have been and/or are working on aspects of the above tasks and that information may already exist on these topics. To meet this ambitious schedule and complete the work expeditiously, existing data and expertise will be utilized to the extent possible, and certain subtasks may be conducted at a broader, rather than overly detailed level. For example, although it will not be possible to conduct a detailed survey (Task 5) it may be possible to obtain informal input at Energy 98 in August in Bellevue, Washington. In addition to information analysis, a workshop will conducted for cognizant $\mathrm{DOE}$ and lab staff following Task 6, to discuss and validate project findings and address strategy development. A detailed schedule will be developed and attached to this SOW.

\section{Task Results and Deliverables}

Task 1. Data characterizations will be made available in listings, database, or other format as deemed appropriate for use in Task 3.

Task 2. Summaries of currently available alternative financing offerings, as well as those offerings under development or under consideration for development, for federal installations by the following organizations will be developed: U.S. Army Corps of Engineers, U.S. Air Force, U.S. Postal Service, the Bonneville Power Administration, FEMP Utility Program, and other public and private sector organizations identified during the performance of this task. Summaries of these alternative financing offerings will be up to 2 pages in length and as a minimum include the following information: brief description of the alternative finance offering, a listing of potential/eligible users/subscribers, summary of significant features of the offering (e.g. contractor selection process), user fees, funding limitations (floors and ceilings), and date of offering availability.

In addition, a summary of federal agency alternative financing programs and policies will be developed. Information to be contained in this summary includes agency policy regarding ESPC implementation (goals, barriers, and preferred providers), current and planned ESPC/Super-ESPC project developments (number and/or dollar volume), agency MOU status and description of MOU level (local, regional, or national), current and planned utility financed projects (number and or dollar volume), projected agency energy efficiency funding appropriations in fiscal years 1999 and beyond, and agency policy/strategy to address the electric market deregulation. Agencies to be included in this summary will at a minimum include the US Army, US Air Force, US Navy, DOE, EPA, GSA, NASA, USPS, VA, and at least 2 more agencies.. 
Task 3. Estimates of the Super-ESPC capital investment level needed to attain the 30 percent reduction goal and Super-ESPC capital investment potential based on agency policies, resources goals, and attributes.

Task 4. Completed resource scenario assessment identifying number of delivery orders needed and expected to reach the needed market target capital investment amount and the required estimated resource requirements necessary to support these investment levels.

Task 5. A summary of information gathered by surveys administered as a part of this task, as well as information from previous surveys covering federal facility energy management such as that by the Alliance to Save Energy and other FEMP program surveys (technical assistance and utilities) will be developed.

Task 6. The results of Task 5 will be used to fine-tune the target market estimates developed in Task 3. A modified resource requirements analysis reflecting the modified target market estimate should also be conducted. As the target market will have become better defined, a summary of this market's attributes will also be developed assisting in the identification of individual sites. A letter report that defines the FEMP Super-ESPC target market and its attributes, as well as another other pertinent conclusions and recommendations, will be developed and available for use during the Task 7 effort.

Task 7. Expected results of this task are summarized below:

- Recommendations for the FEMP Outreach, Communications, and Education Plan which is scheduled for completion in November 1998;

- Strategies for FEMP regional staff to identify and prioritize Super-ESPC outreach efforts;

- Recommendations on ways to assist Super-ESPC contractors identify target sites; and

- Recommendations on applying and integrating the project findings into the operation of the FSN.

\section{Additional Products.}

Interim Report: Pending availability of funds, an interim report will be developed following the completion of Task 4. This report will provide a status update on all project activities and a quick summary of observations, recommendations, and conclusions to date.

Final Report: A final letter report summarizing conclusions, recommendations, and the work performed under each task will be developed following the completion of Task 7. 


\section{Energy '98 Federal Staff Survey Results}

These are the tabulated results for the Federal Staff Survey that was administered at the DOE FEMP Energy ' 98 conference in Bellevue, Washington, August 3-5, 1998, and also over the FEMP Home Page (posted September 9, 1998). Additional comments appear in shaded areas.

Your Responsibilities:

Please check the position description below that best characterizes your job?
$\underline{5} \quad$ Facility manager
$11 \quad$ Engineering/design staff
$3 \quad$ Facility manager office staff
10 Agency energy management
$7 \quad$ Maintenance staff
$\underline{14}$ Site energy manager/energy engineer/energy coordinator
9 Other -- Please describe: Contract specialist, acquisition contracting officer, $R \& D$, financial analyst - planning and budgeting, district environmental compliance coordinator, environment and facility manager, maintenance manager, engineering and contacting for energy conservation, and engineer with national lab.

Site Information: Results not tabulated.

\section{- $\quad$ For what agency do you work?}

- Site staff only:
$-\quad$ In what state is your facility located?
$-\quad$ What is the approximate total building square footage?
$-\quad$ Approximately how many buildings are located on your site?
Estimate the cost effective energy efficiency retrofit savings potential still available
at your site: $\quad \%$ and/or $\quad$ S/year

Facility Investment Priorities:

What importance do each of these items play in making decisions on which types of projects will be supported (technical staffing and/or funding)? Scale: $5=$ very important, $4=$ important, $3=$ neutral/don't know, 2 = not important, and $1=$ irrelevant: Average scores shown.

4.3 Direct mission support

$\underline{3.9}$ Occupant satisfaction/tenant needs

3.0 Maintain status quo

4.1 Meeting energy reduction goals

$\underline{3.7}$ Command/management direction

_ Other, please describe:
3.7 Reducing environmental emissions

4.3 Saving operations dollars

3.9 Life-cycle costs

4.3 Availability of appropriated funds

4.1 Agency-wide policy initiatives (e.g. CFC

conversions and indoor air quality)

Investment Options:

What is the likelihood of funding new energy efficiency projects at your site via the funding methods listed below? Scale: $5=$ will happen, $4=$ somewhat likely to happen, $3=$ uncertain, $2=$ not likely, and $1=$ will not happen: Average scores shown.
$\underline{3.9}$
$\underline{3.1}$
Agency appropriated energy funds
$\underline{3.4}$ Site specific energy savings performan
$\underline{2.5}$ Other agency ESPC vehicle (e.g. Corps of Engineers 46 state contract and others)
3.4 Utility financing
Other, please describe: "Resource Efficiency Manager" was scored as a "4" on one survey.
"Utility incentives programs if available" was scored as a " 4 " on one survey.

Site Energy Management Strategy:

Please rank in order of priority (" 1 " being the highest and " 7 " being the lowest) each of the following 
approaches/strategies as they fit into your site's overall energy management strategy: Average scores shown.

2.3 Use appropriated funding to identify and implement energy efficiency projects

3.6 Use performance contracting (ESPC) to fund energy efficiency retrofit projects

3.9 Use utility financing to fund energy efficiency retrofit projects

4.5 Procure utilities via state electric market deregulation and/or aggregated power purchases

3.4 Conduct energy awareness campaigns

3.1 Continue/improve operations and maintenance practices of energy using systems

- Other(s), please list: "Funding through previous savings" was scored as a " 1 " in one survey.

Site Technical and Contracting Skills:

Do the staff at your site have the technical and/or contracting experience and background in the following areas necessary to fully implement ESPC or utility financed projects: (answer Yes, No, or include comment)

- Energy auditing/project identification

- Energy project design

- ESPC development and awards

- Utility rate negotiation and procurement

- Measurement and verification of energy savings $\underline{36}$ Yes 15 No 2 Maybe

Obtaining Technical and Contracting Skills:

The recently established FEMP Service Network (FSN) makes available the full range of technical services necessary to implement energy efficiency projects, especially projects that apply alternative financing methods (ESPC and utility financing). These services are available to Federal sites on a cost reimbursable basis. Repayment for services may take place over several years as allowed for under the special authorization received from Congress. The questions below apply to your site's potential interest in using the FSN as a project development technical service provider:

- Would you/your site consider the FSN as a technical service provider? 23 Yes $\underline{9}$ No 19 Need to learn more

- Would your site be interested in obtaining project development technical support services under a deferred payment arrangement? 27 Yes 18 No

- Based on your site's current energy management strategy and needs, what do you feel is the likelihood of using the FSN to provide some level of support to your energy efficiency project development? Check one: 6 very likely, 12 likely, 26 don't know, 44 unlikely, 22 will not happen

- What service(s) do you feel the FSN should offer to best assist you in your project development/implementation efforts?

Additional Comments: Please write any additional comments you have regarding site and/or Federal energy efficiency efforts:

Optional Follow-Up Survey: Are you available for an additional follow-up survey on site energy management needs and FSN service offerings? If so, please provide the requested information below: Name:

Phone Number: Agency: e-mail:

Please return completed forms to the drop box labeled "Conference Evaluation Forms" at the conference registration desk. Thank you for your time in completing this survey. Please enjoy your visit to Energy '98. 
This survey is being administered in support of the Federal Energy Management Program's (FEMP's) current initiative to determine energy efficiency procurement trends and technical support needs. The instructions are pretty straight-forward - answer the questions as appropriate. In some cases you will be asked for information that you may not have readily available, in which case we ask for your best guess. Please feel free to contact Dave Hunt at (202) 646-7867 or dave.hunt@pnl.gov if you have a question regarding information that is being requested in this survey. Please note that this survey is not being conducted on a confidential basis as agency specific information is being requested. Please be assured that this is necessary in order for us meet our primary survey objective of identifying agency technical support needs. Your response is requested no later than August 7, 1998 as this information is needed to assist us in our fiscal year 1999 resource allocation efforts. Please return completed surveys to Dave Hunt either by fax at (202) 646-5233 or to the e-mail address noted above. Your participation in this survey is greatly appreciated and will help in FEMP's efforts to be more responsive to your agency's needs.

Agency you represent:

Agency Appropriations:

How much are your agency's appropriations for energy efficiency projects during the fiscal year:

$-\quad 1998 ?$

1999 (best estimate)?

Estimated Savings Potential:

Provide your best estimates to the following:

- The average age of the agency's building inventory is years.

- The remaining energy savings potential available through cost effective actions for your agency's facilities is percent and/or dollars per year.

- A total investment of be made in your agency's facilities. dollars in cost-effective energy-efficiency retrofits can

Agency Energy Management Strategy:

Please rank in order of priority (" 1 " being the highest and " 7 " being the lowest) each of the following approaches/strategies as they fit into to your agency's overall energy management strategy:

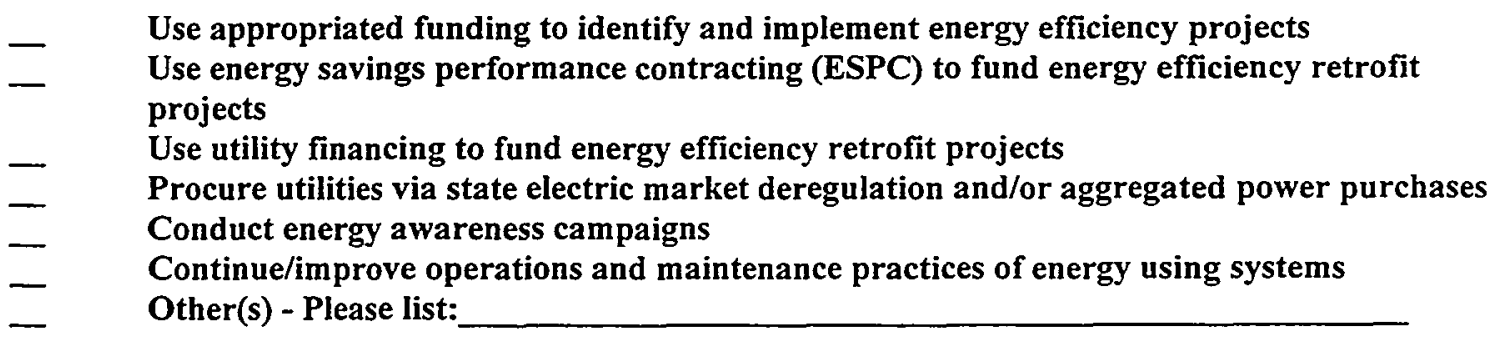

Energy Management Staffing Levels:

Provide your best estimates to the following:

- What percentage of your sites have full time energy managers?

- What percentage of your sites have part time energy managers?

- What approximately is the total number of site energy managers within your agency? 
Energy Manager Backgrounds:

Estimate the percentage of site energy managers that have the project experience and/or training necessary to do the following:

- Perform energy audits and identify and design energy projects:

- Develop, negotiate, and manage ESPCs (inclusive of Super-ESPCs):

- Negotiate utility rates and/or customized utility services such as project financing:

- $\quad$ Develop energy retrofit project measurement and verification plans:

Project Development:

At what level/levels are energy efficiency projects initiated within your agency? (Please check all that apply.) If more than one level, signify the one level which has lead responsibility for initiating energy efficiency project development.

\begin{tabular}{|l|l|l|}
\hline $\begin{array}{l}\text { Level at which energy-efficiency } \\
\text { projects are initiated }\end{array}$ & $\begin{array}{l}\text { Initiates projects } \\
\text { (check all that } \\
\text { apply) }\end{array}$ & $\begin{array}{l}\text { Lead responsibility } \\
\text { for initiating } \\
\text { projects } \\
\text { (check one only) }\end{array}$ \\
\hline - Local building/facility & & \\
\hline - Regional office & & \\
\hline - National office & & \\
\hline - Other: please specify & & \\
\hline
\end{tabular}

Project Approvals:

At what level/levels are decisions made to implement energy efficiency projects? (Please check all that apply.) If decisions are made at more than one level, which of these levels has the primary project approval authority.

\begin{tabular}{|l|l|l|}
\hline $\begin{array}{l}\text { Decision level at which energy-efficiency } \\
\text { projects are approved }\end{array}$ & $\begin{array}{l}\text { Involved in } \\
\text { decision process } \\
\text { (check all that } \\
\text { apply) }\end{array}$ & $\begin{array}{l}\text { Primary project } \\
\text { approval } \\
\text { authority } \\
\text { (check one only) }\end{array}$ \\
\hline Site energy manager & & \\
\hline Building/facility manager & & \\
\hline Site tenants & & \\
\hline Regional energy manager & & \\
\hline Other regional staff & & \\
\hline Headquarters energy management staff & & \\
\hline Other headquarters staff & & \\
\hline Other: please specify & & \\
\hline
\end{tabular}




\section{Energy Savings Performance Contracts:}

To Date:

a) How many ESPCs have your facilities implemented (include all projects currently in the request for proposal (RFP) stage and beyond) to date?

b) What is the estimated total value of capital improvement resulting from these ESPC projects?

Fiscal Year 1999:

a) How many ESPC RFPs does your agency anticipate issuing during fiscal year 1999 ?

b) What is the anticipated total value of capital improvement that will result from these ESPC projects?

Utility Project Financing:

To Date:

a) Aside from demand side management rebate programs, how many utility financed projects have your facilities implemented (agreements signed) to date?

b) What is the estimated total value of capital improvement resulting from these utility financed projects?

Fiscal Year 1999:

a) How many utility financed projects does your agency plan to implement (agreement signed) during fiscal year 1999?

b) What is the anticipated total value of capital improvement that will result from these utility financed projects?

General Questions:

Please indicate if you agree or disagree with the following statements.

a) In general for my agency, decision makers are comfortable implementing projects via alternative financing (ESPC and utility financing) methods. __ Agree _ Disagree

b) Sites in my agency would be interested in obtaining energy efficiency retrofit project technical assistance (i.e. project identification, data collection, utility contract analysis and rate negotiation/procurement, measurement and verification, Super- ESPC delivery order development assistance, proposal evaluation guidance, and/or contract negotiation) on a cost reimbursable basis with deferred payments to FEMP made over several years via the FEMP Service Network (FSN). Agree Disagree

c) The availability of project technical assistance on a deferred payment basis as offered by the FSN will (please check one)

- significantly increase interest at the site level to implement Super-ESPC delivery orders

- increase interest at the site level to implement Super-ESPC delivery orders

- not impact interest at the site level to implement Super-ESPC delivery orders

Generàl Comments: Is there any other information you would like to share regarding your agency's energy management policies and/or planned activities?

Thank you for taking the time to complete this survey! Please return completed survey to Dave Hunt either electronically (dave.hunt@pnl.gov) or via facsimile at (202) 646-5233. 
Input from the 9/1/98 FEMP Workshop to Determine the Potential Market for FEMP ESPC Delivery Orders

Specific Topic: Determine Selection Criteria for Prioritizing REAP Marketing Resources

Approach: List all candidate criteria and then have participants vote for their "top 4"

Input from: G. Courville, D. Culbreth, B. Gustafson, D. Howard, D. Hunt, J. Watson, J. Woods

The top 4 Criteria

1) Site energy intensity (BTU per GSF)

(7 VOTES)

2) Total agency GSF (e.g. VA and GSA)

(7 VOTES)

3) Is there agency support for efficiency? (At HQ, within regions, local?) (5 VOTES)

TIED with 3 Votes each:

4) Regional concentrations of agency sites: tailor marketing approach to region

4) What is the transactions cost of marketing? (If low, "small" facility may be attractive.)

\section{Other Criteria}

1) Agency plans for the space in the future

(2 VOTES)

2) Is the floor space rented or owned?

(1 VOTE)

3) Does MOU exist with Agency?

4) Utility rate structure (e.g., cost per kWh)

5) Available data on "benchmark" buildings - typical consumption by type, region

6) Total magnitude of agency energy use

7) Does an internal champion exist for efficiency at site?

8) Are there "agencies" within Departments with separate decision makers that may be receptive to FSN services?

9) Potential for follow-on business (GSA relative to Dept of Labor)

10) Is efficiency anywhere in the Agency's stated mission objectives?

11) Availability of Agency staff time and resources

12) Long-term plans for capital upgrades such as at GSA (prospectus)

13) What's the opportunity for efficiency improvement? Any "been there, done that" attitude? 


\section{Key Background Questions to Consider in Prioritizing Marketing Efforts}

Note: This list of questions was developed in round-the-room fashion prior to development of the Selection Criteria List

1) Do we even have sufficient data to begin an effort at prioritizing? Aren't more data, and more experience with the FSN and agencies, needed before we prioritize?

2) What are the capital improvement opportunities?

3) Which agencies are major efficiency targets?

4) What is the appropriate "sales style:" corporate account, or "door-to-door?"

5) Where and how is the decision made within an agency? Is it "command and control" or disaggregate/regional decision making?

6) There may be "agencies" within a Department (e.g. Park Service with DOI) with autonomous decision makers. How should they be marketed?

7) Is the approach active marketing or partnering with interested agencies?

8) Return on investment? One USAF base may be huge opportunity.

9) Should the FSN provide "enlightenment" services about the full menu of FEMP activities beyond delivery order services? Including utility financing, technical assistance? 


\section{Distribution}

No. of

Copies

\section{OFFSITE}

Lawrence Berkeley National Laboratory Building Technologies Department, Applications Team 1250 Maryland Ave, S.W. \#500

Washington, DC 20024

Attn: Bill Carroll

National Renewable Energy Laboratory 1617 Cole Blvd.

Golden, CO 80401-3393

Attn: Mary Colvin

National Renewable Energy Laboratory $40912^{\text {th }}$ Street SW, Suite 710

Washington, DC 20024-2125

Attn: Dave Howard

Oak Ridge National Laboratory

PO Box 2008

Building 3147

Oak Ridge, TN 37831-6070

Attn: Patrick Hughes

U.S. Department of Energy

1000 Independence Avenue, SW

Washington, DC 20585

Attn: B. Gustafson, EE-92, Room 6B-

052

U.S. Department of Energy

1000 Independence Avenue, SW

Washington, DC 20585

Attn: T. Muessel, EE-92, Room 6B-

052

U.S. Department of Energy

1000 Independence Avenue, SW

Washington, DC 20585

Attn: B. Shearer, EE-92, Room 6B-052
No. of

Copies

U.S. Department of Energy

Atlanta Regional Office

730 Peachtree Street, NE, Suite 876

Atlanta, GA 30308

Attn: David Waldrop

U.S. Department of Energy

Boston Regional Office

JFK Federal Bldg, Rm 675

Boston, MA 02203

Attn: Paul King

U.S. Department of Energy

Chicago Regional Office

1 South Wacker Drive, Suite 2380

Chicago, IL 60606

Attn: Sharon Gill

U.S. Department of Energy

Denver Regional Office

1617 Cole Blvd.

Golden, CO 80401

Attn: Randy Jones

U.S. Department of Energy

26 Federal Plaza \#39-105

New York, NY 10278

Attn: Bill Klebous

U.S. Department of Energy

Seattle Regional Office

800 Fifth Avenue, Suite 3950

Seattle, WA 98104

Attn: Cheri Sayer

\section{ONSITE}

$\begin{array}{ll}\text { D. Hunt (25) } & \text { BWO } \\ \text { K. McMordie (10) } & \text { Offsite } \\ \text { W. Sandusky (2) } & \text { K5-08 } \\ \text { Information Release (7) } & \text { K1-06 }\end{array}$

